\title{
23
}

\section{Government transfer payments and regional development}

\section{Tingsong Jiang and Zhiyun Zhao}

Rapid economic change in China has been accompanied by worsening regional disparity. The income gap between China's coastal and inland regions ${ }^{1}$ has been widening since the economic reforms began in 1978 (Figure 23.1). Of the three regions, the Eastern coastal region (the richest region) experienced the fastest economic growth in the past two decades. Average per capita GDP in the Eastern region increased sevenfold, while per capita GDP in the Western region (the poorest region) increased less than fivefold. The gap in per capita GDP between the Eastern and Western regions increased from 380.6 yuan in 1978 to $3,354.9$ yuan in 2000 in real terms. This phenomenon has been well documented by many authors, for example, Wu (1999), Sun (2000), Sun and Parikh (2001) and Jiang (2002).

One way to tackle this problem is to use intergovernment transfer payments. ${ }^{2}$ Transfer payments could ease the regional disparity through three channels. First, payments to households in less developed regions could directly narrow the regional income gap. Second, transfer payments to finance more investment in health, education and infrastructure in less developed regions could improve these regions' economic growth potential and ease the disparity in the longer term. Third, transfer payments may reduce the tax burden in the recipient regions and thus give additional stimulation to their economies.

Transfer payments have played an important role in local government budgets in China. In 2001, about 41.3 per cent of local government revenues were transfers 
Figure 23.1 Per capita GDP
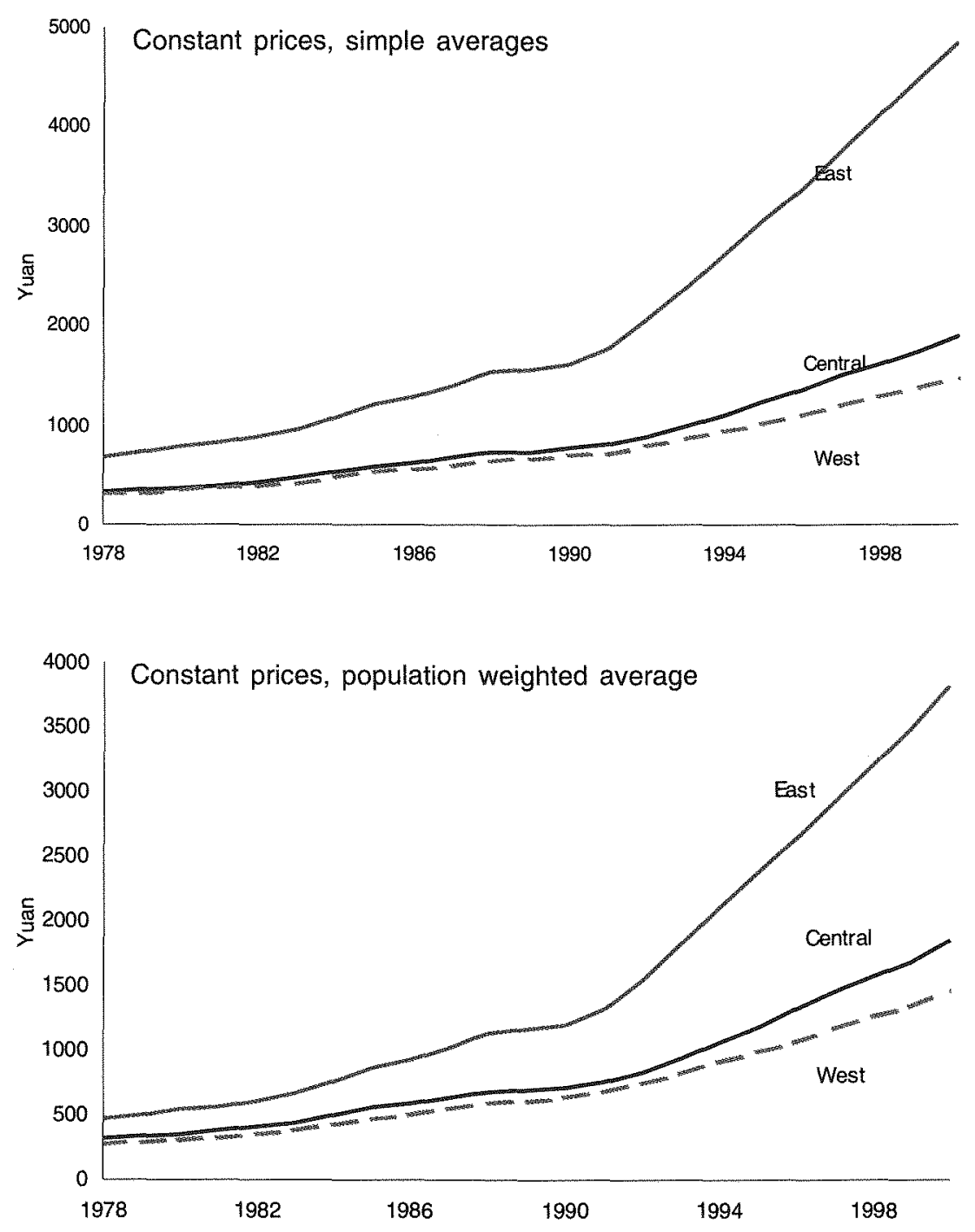

Source: Jiang, T., 2003. 'The impact of China's WTO accession on its regional economies', Australian Agribusiness Review, forthcoming. 


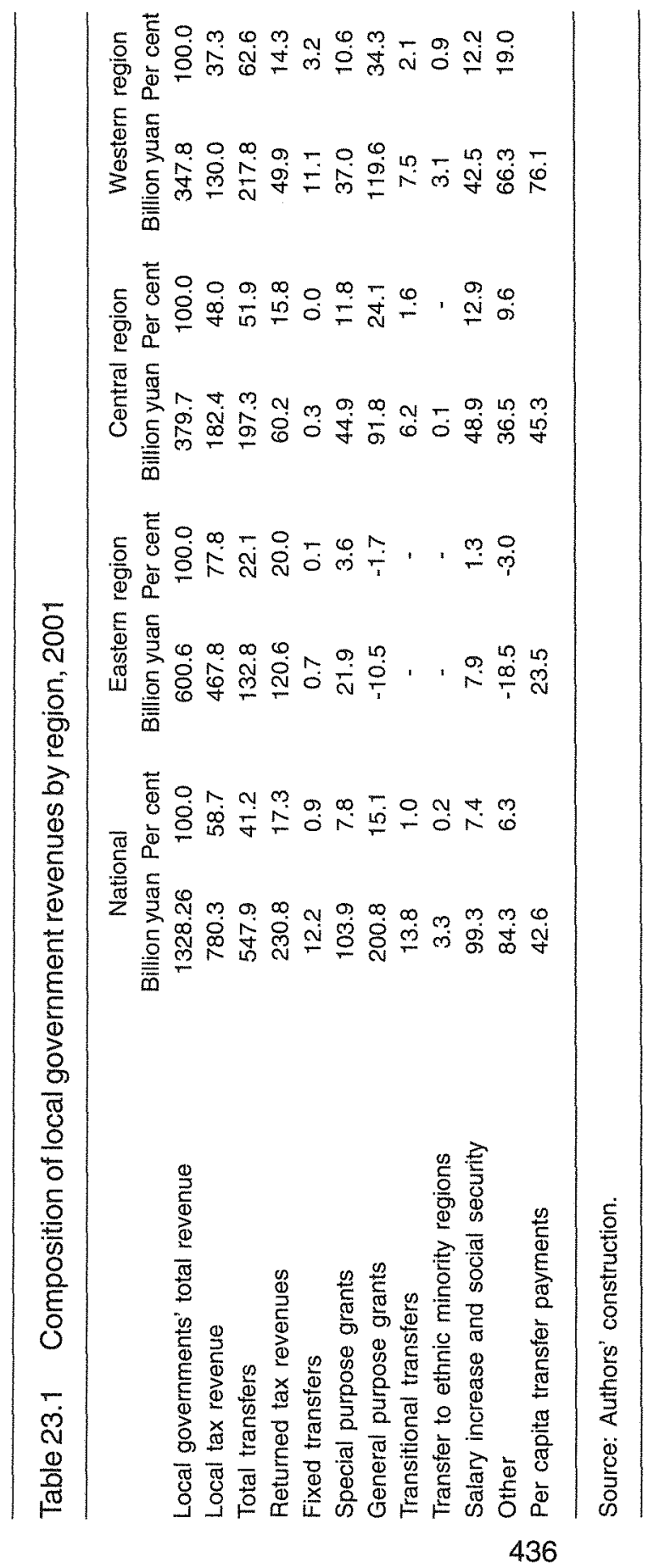


from the central government (Table 23.1). Most of these transfers, however, were purely tax revenues that were redistributed among the central and local governments through the tax sharing system (fen shui zhi). Only a very small proportion of transfers are dedicated to lessening the regional disparity. The share of the 'equalisation transfer' in total transfer payments from the central to the local governments was only 1.8 per cent in 2000 (He 2001). Therefore, many studies find that the transfer system failed to equalise per capita fiscal expenditure and per capita income (for example, Wong 2002a; Ma 2003). ${ }^{3}$

\section{GOVERNMENT TRANSFER PAYMENT SCHEMES}

China's government transfer payment practices have evolved along with its fiscal system. Before the economic reforms of 1978 there were no systematic transfer payments. Transfer payments, as supplementary measures, were made within other fiscal instruments under a centralised fiscal system. Public finances were gradually decentralised under the fiscal contract system (caizheng baogan zi) implemented in the 1980s and early 1990s, until the implementation of the tax sharing system in 1994. The implementation of the Transfer Payment Arrangement during the transitional period in 1996 marked the establishment of a formal and comprehensive program of government transfer payments. Thus, the evolution of transfer payment schemes can be divided into four periods: pre 1979, 1980-93, 1994-95 and post 1996.

\section{Transfer payments before 1979}

Before 1979, the Chinese economy was centrally planned and local governments' finance was strongly controlled by the central government. Revenues were allocated between central and provincial governments according to pre-defined shares. Under this fiscal regime, the central government's transfer payments to local governments took the form of 'deficit subsidy' and 'special purpose grants'.

On the basis of these pre-defined terms, the central government examined local governments' actual revenue and expenditure. Local governments either remitted all their surpluses to, or received full subsidy from, the central government to balance their deficits. The central government also provided grants to local governments in special cases such as natural disasters and large infrastructure projects. 
Although the form of transfer payment was simple during this period, the amount was usually large.

\section{Transfer payments between 1980 and 1993}

Between 1980 and 1993, as part of China's economic reform, government finance was gradually decentralised and a governmental fiscal contract system established. Under this system, the scope and base of revenues and expenditures was defined jointly by the central and local governments and local governments were responsible for the balance of their budgets. Transfer payments occurred in three forms-fixed transier, earmarked special purpose grants, and settlement subsidies.

Fixed transfer was guaranteed by the contract system for those local governments whose base revenues did not cover defined expenditures. The amount of this type of transfer payment was fixed by the level of the deficit in the base year. However, additional settlement subsidies and special purpose grants could still be available. Settlement subsidies were made when items of revenues and/or expenditures defined in the contract were changed, for example, when the ownership of firms transferred from the central government to local governments or vice versa. Special purpose grants were paid in two forms. Some were earmarked to finance special programs, such as agricultural support, large infrastructure projects, and so on. Others were used in the case of natural disasters.

Transfer payments during this period were diversified and informal. In 1988, for example, there were nine forms of fixed transfers, 21 forms of special purpose grants and 15 forms of settlement subsidies. Administrative costs were therefore high, and efficiency low.

\section{Transfer payments between 1994 and 1995}

In 1994, as part of a comprehensive tax reform package, the central government replaced the fiscal-contract system with a tax-sharing system. Under this system, tax revenues received by the central and local governments were clearly defined and collected by different agencies. Tax revenues assigned to the central government included customs duties, excises and value added tax (VAT) on imports; excise; enterprise income tax collected from central government-owned enterprises; taxes collected from railways, headquarters of banks and insurance companies; 75 per cent of domestic VAT; and 91 per cent of security stamp duty. Tax revenues assigned to local governments included 25 per cent of domestic VAT; business tax except 
that collected from railways, banks and insurance companies; company income tax except that collected from central government-owned enterprises; personal income tax; resources tax; urban maintenance and construction tax; real estate tax; agricultural tax and others (Zhang 2002).

As a result of the tax-sharing system, the central government's revenue, and thus the transfer payments, increased significantly. In 1994 and 1995, transfer payments to local governments amounted to 213 and 245 billion yuan, accounting for 78 and 76 per cent of the central government's revenue, and 60 and 52 per cent of local governments' expenditure, respectively (Du 2001:49). Most of the transfer payments were in the form of 'returned revenues', which were designed to ensure that local governments' revenues after the implementation of the tax assignment system did not fall below the 1993 level. The returned revenues, accounting for 77 per cent of total transfer payments in 1995, were not a real increment to the transfer payment as they were originally part of the local governments' revenues. Nevertheless, they provided the central government more room to use fiscal instruments. The remaining transfer payments were equivalent to previous settlement, fixed transfer and special purpose grants.

\section{Transfer payments after 1996}

In 1996, transfer payments were formalised and systematised when the Transfer Payment Arrangement was implemented. These 'transitional' transfer payments consisted of two parts: objective factor-determined transfer payments and policybased transfer payments. The amount of objective factor-determined transfer payments $\left(T O_{i}\right)$ is calculated according to the formula,

$$
T O_{i}=\left(E_{i}-R_{i}\right) \times a
$$

where $E_{i}$ and $R_{i}$ are respectively region is standard fiscal revenues and expenditures, and $a$ is the coefficient of objective factor-determined transfer payment, which is in turn determined by

$$
a=\frac{T-T P}{R-E}
$$

where $T$ is the total amount of transfer payments nationwide, TP is the amount of national policy based transfer payments, and $R$ and $E$ are, respectively, national standard fiscal revenues and expenditures. No objective factor-determined transfer payments are made to regions with more revenues than expenditures. 
Policy-based transfer payments were dedicated to ethnic minority autonomous regions, according to the difference between regional standard fiscal revenue and expenditure. The amount of this type of transfer payment was affected by two factors: the difference of fiscal capacity in the growth rate, and the difference in fiscal capacity per capita, between the nation and the particular region (Ma 1998:94).

In 1998, some changes were made to the Transfer Payment Arrangement, mainly involving the adjustment of the calculation of standard fiscal revenues and expenditures. In 2002, a new decree, the General Transfer Payment Arrangement, was promulgated, mainly to address the issue of transfer payments to the inland regions. General transfer payments were similar to the objective factor-determined transfer payments, except that the transfer payment coefficient differed across regions (Ministry of Finance Budget Department 2003).

However, the 'transitional transfer payment' played a very limited role because it accounted for only a small proportion of total transfer payments, just above 2.5 per cent in 2001 . In the Eastern, Central and Western regions, its share in local governments' total revenues was only $0.01,1.63$ and 2.17 per cent, respectively (Table 23.1).

At present, 41.3 per cent of local governments' total fiscal revenues are from transfer payments from the central government (Table 23.1). These transfers fall into four broad categories-fixed transfer, returned tax revenue, special purpose grants, and general purpose grants. General purpose grants include transitional transfers, transfers to ethnic minority regions, transfers to increase the salaries of public servants and improve social security networks, and other grants, such as settlement subsidies. The shares of these four categories in total transfer payments are shown in Figure 23.2.

\section{AN EVALUATION OF THE TRANSFER PAYMENT SYSTEM}

The impact of transfer payments on regional development can be examined from two aspects-whether the structure of transfer payments is appropriate to address the problem of regional disparity, and whether the transfer payments actually contributed to regional fiscal equalisation and growth convergence.

\section{Are richer provinces receiving more transfer payments?}

It is often argued that the transfer payments in China have failed to ease regional disparity, as richer regions receive even more transfers than poor regions (Ma 2003). This could happen for two reasons. First, the central government collects more 
taxes from the more developed regions, and under the tax-sharing system these regions receive more transfers in the form of returned tax revenue (Table 23.1). Second, the transfer payment system is virtually a negotiable scheme, meaning developed regions can receive fairly large amount of transfers in other forms.

The situation has changed, however, and this concern may no longer be valid. Although richer regions still receive more transfers in the form of returned tax revenues, poorer regions receive more transfers in total. As shown in Table 23.1, the total amount of transfer payments in 2001 to the Central and Western regions was, respectively, double and three times the amount of transfer payments to the Eastern region.

This pattern is also evident at the provincial level. Figure 23.3 plots per capita total transfer payments (23.3a) and per capita transfer payments other than returned revenues (23.3b) received by each province, autonomous region or municipality against its per capita GDP in 2000 . It can be seen from the charts that there is a negative relationship between per capita transfers and per capita GDP.

Figure 23.2 Composition of transfer payments by region, 2001

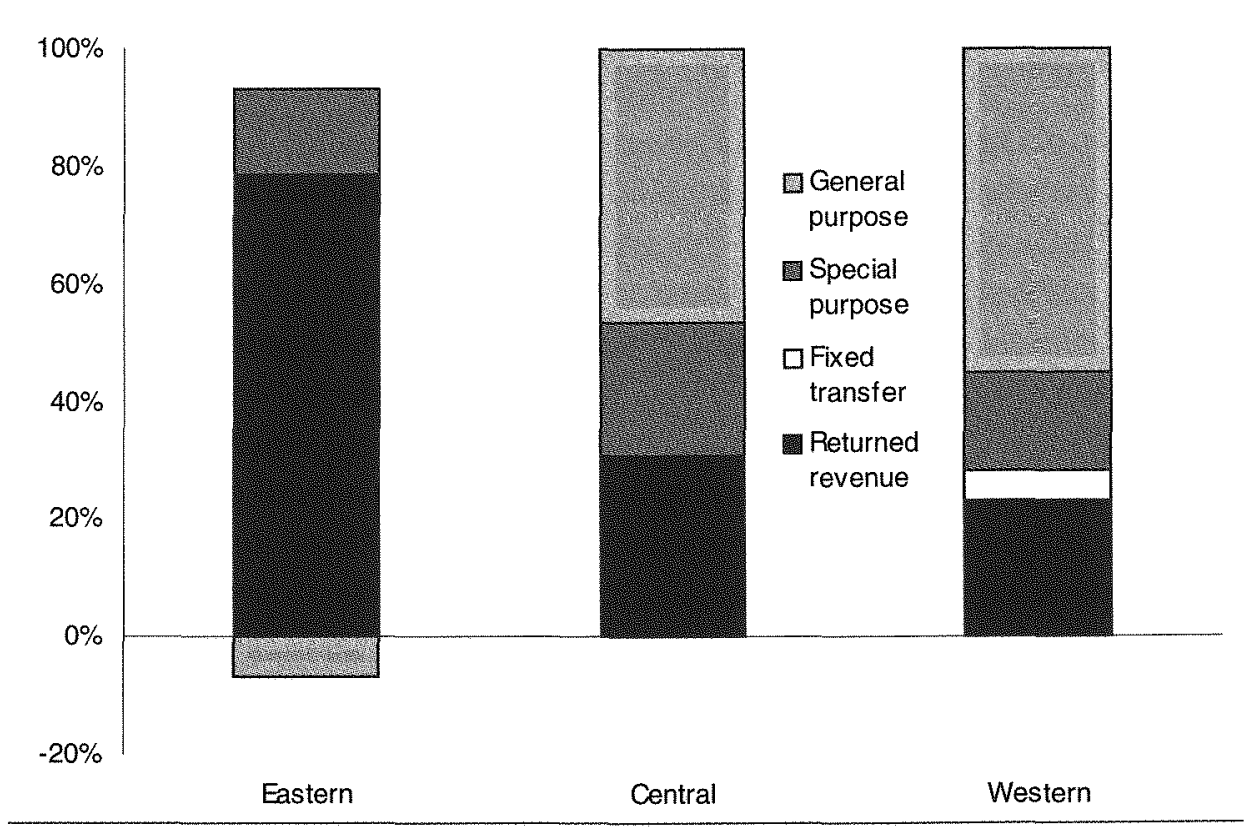

Source: Authors' construction based on statistics 
This is confirmed by the following OLS regressions of per capita transfer payments against per capita GDP:

$$
\begin{aligned}
P_{C T T_{i}=} & 543.359-0.0210 P C G D P_{i} \\
& (5.19) \quad(1.50) \\
\text { PCTO }_{i}= & 533.222-0.0296 P C G D P_{i} \\
(4.29) & (2.56)
\end{aligned}
$$

where $P C T T_{i}, P_{C T O}$ and $P C G D P_{i}$ are, respectively, per capita total transfer payments, per capita transfer payments other than returned revenues, and per capita GDP in province $i$; and numbers in brackets under the equation are t-ratios for estimated coefficients. It can be seen that there is a significant (at 5 per cent level) negative relationship between per capita GDP and other transfers. That is, poorer regions receive more transfers than returned revenues from the central government. There is a weaker negative relationship between per capita total transfer payments and per capita GDP if the outliers-Shanghai, Beijing, Tianjin and Shanghai-are excluded.

This indicates that in recent years poorer regions have received more transfer payments from the central government than richer regions.

\section{TRANSFER PAYMENTS AND REGIONAL FISCAL INEQUALITY}

The pattern of China's regional fiscal inequality has been changing over time while the impact of transfer payments on regional fiscal capacity has been a debatable issue.

Under the fiscal-contract system that prevailed during the 1980 s and early 1990 s, China's fiscal system was decentralised and regional governments were required to finance themselves. Economists have been concerned that regional self-finance may have worsened the inequalities. Jin et al. (1999), however, find that regional fiscal inequality actually improved during the fiscal contract system period.

Table 23.2 reports the coefficients of variation for per capita revenue and expenditure across provinces between 1982 and 1992. It shows that the regional disparity for budgetary and extra-budgetary revenues and expenditures improved over the period. For example, the coefficient of variation for budgetary revenue fell from 1.99 in 1982 to 0.98 in 1992 . On the other hand, the coefficient of variation for per capita budgetary revenue remittance (the difference between budgetary revenue and expenditure) rose from 4.25 in 1982 to 7.78 in 1992, implying greater revenue redistribution from rich to poor provinces. In other words, the transfer payments helped ease regional fiscal inequality during the period. 
Figure 23.3 The relationship between regional income and transfer payments, 2000

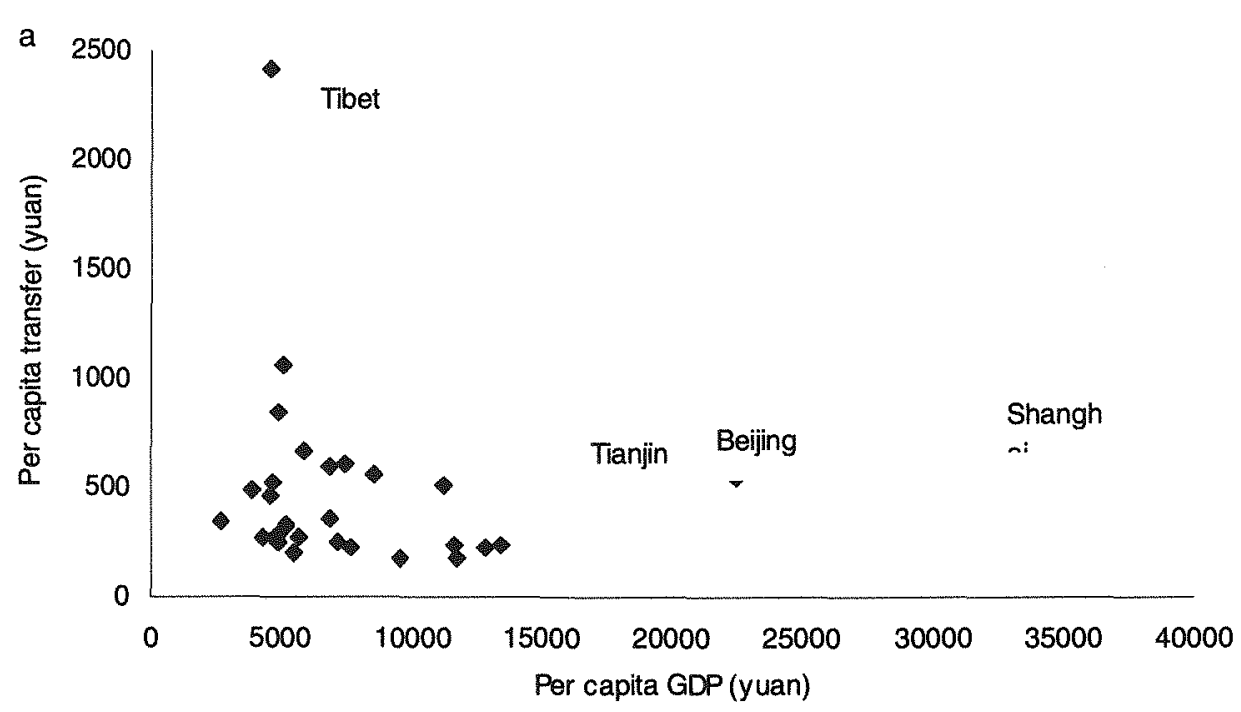

b

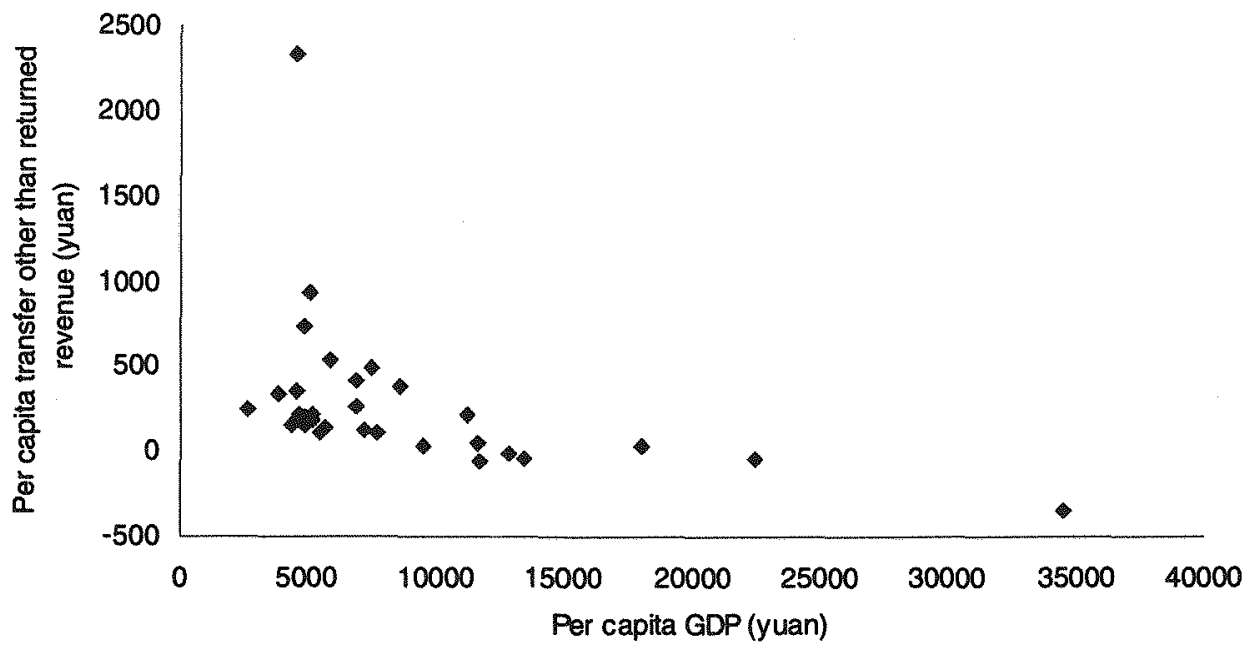

Note: a per capita total transfer payments vs per capita GDP b per capita transfer payments other than returned tax revenues vs per capita GDP 
Wong (2002a) observes that regional fiscal inequality started worsening in 1993. For example, the coefficients of variation for per capita expenditure rose from 0.534 in 1992 to 0.675 in 1998, and the maximum to minimum ratio jumped from 6.6 to 19.1 during the same period (Table 23.3). Based on these observations, Wong argues that the transfer payment system failed to equalise.

However, it seems that regional fiscal inequality has improved in recent years. Both the maximum to minimum ratio and the coefficient of variation for per capita revenue and expenditure were lower in 2001 than in 1998 (Table 23.3). Because our data sources and variable definitions may be different to Wong's (2002a), our results may not be directly comparable with hers. The results for 2000 and 2001, however, are comparable as they have consistent data sources and definition. At least for these two years, there was an improvement in regional fiscal inequality.

Table 23.1 shows that, in 2001, the Eastern, Central and Western regions received $24.2,36.0$ and 39.8 per cent respectively, of the central government's transfer payments. Given that these regions account for $42.5,34.8$ and 23.7 per cent of the Chinese population, respectively, it is clear that the improvement in regional fiscal inequality was a result of increasing transfer payments from the central government to less developed regions.

Table 23.2 The coefficients of variation for per capita revenue and expenditure across provinces, 1982-92

\begin{tabular}{lccccc}
\hline & $\begin{array}{c}\text { Budgetary } \\
\text { revenue }\end{array}$ & $\begin{array}{c}\text { Budgetary } \\
\text { expenditure }\end{array}$ & $\begin{array}{c}\text { Budgetary } \\
\text { revenue } \\
\text { remittance }\end{array}$ & $\begin{array}{c}\text { Extra- } \\
\text { budgetary } \\
\text { revenue }\end{array}$ & $\begin{array}{c}\text { Extra- } \\
\text { budgetary } \\
\text { expenditure }\end{array}$ \\
1982 & 1.9 & 0.6 & 4.2 & 1.0 & 0.8 \\
1983 & 1.8 & 0.6 & 5.0 & 1.0 & 0.9 \\
1984 & 1.7 & 0.6 & 6.1 & 1.0 & 1.0 \\
1985 & 1.6 & 0.6 & 6.9 & 1.0 & 0.9 \\
1986 & 1.5 & 0.6 & 5.3 & 1.0 & 1.0 \\
1987 & 1.3 & 0.5 & 3.9 & 1.0 & 1.0 \\
1988 & 1.2 & 0.5 & 4.5 & 1.0 & 1.0 \\
1989 & 1.0 & 0.5 & 4.8 & 0.9 & 0.9 \\
1990 & 1.0 & 0.5 & 6.2 & 0.9 & 0.9 \\
1991 & 0.9 & 0.5 & 6.1 & 0.9 & 0.9 \\
1992 & 0.9 & 0.5 & 7.7 & 0.8 & 0.8 \\
\hline
\end{tabular}

Source: Jin, H., Quian, Y., and Weingast, B.R., 1999. Regional decentralisation and fiscal incentives: federalism, Chinese style, Stanford University, Stanford, unpublished:Table 22.6. 


\section{TRANSFER PAYMENTS AND REGIONAL ECONOMIC GROWTH}

The ultimate purpose of transfer payments is to stimulate regional economic growth. Jiang (2002) observes a divergence of per capita income in Chinese provinces, autonomous regions and municipalities after 1995. One way to evaluate the impact of transfer payments on regional disparity is to examine whether payments have contributed to this divergence.

$\mathrm{Ma}$ (2003) presents an econometric analysis of the impact of transfer payments on regional growth. He estimates the following regional economic growth equations using regional data from 1995 and 2000

$$
\begin{aligned}
& \ln Y_{i T}-\ln Y_{i 0}=C-\left(1-e^{-\beta T}\right) \ln Y_{i 0}+\varepsilon_{i}, \\
& \ln Y_{i T}-\ln Y_{i 0}=C-\left(1-e^{-\beta T}\right) \ln Y_{i 0}+\gamma T R A N S F_{i}+\varepsilon_{i},
\end{aligned}
$$

where $Y_{i o}$ and $Y_{i T}$ are, respectively, per capita GDP of province $i$ in year 0 and year $T ;$ TRANSF $_{i}$ is the per capita transfer payment received by province $i$ during the

Table 23.3 Trends in the inter-regional distribution of fiscal resources, 1990-2001

\begin{tabular}{ccccccc}
\hline & \multicolumn{3}{c}{ Per capita expenditure (yuan) } & \multicolumn{3}{c}{ Per capita revenue (yuan) } \\
& Max./Min. & Average & Coeff. var. & Max./Min. & Average & Coeff. var. \\
1990 & 6.1 & 241.0 & 0.551 & 17.5 & 227.0 & 1.084 \\
1991 & 6.6 & 268.0 & 0.539 & 16.5 & 256.4 & 1.007 \\
1992 & 6.6 & 282.9 & 0.534 & 15.8 & 271.0 & 0.998 \\
1993 & 8.1 & 355.5 & 0.546 & 15.0 & 360.9 & 0.940 \\
1994 & 9.7 & 417.6 & 0.665 & 15.2 & 271.6 & 0.992 \\
1995 & 16.6 & 512.2 & 0.768 & 16.3 & 333.5 & 1.010 \\
1996 & 18.1 & 612.7 & 0.801 & 15.9 & 413.7 & 1.029 \\
1997 & 19.5 & 708.8 & 0.882 & 16.8 & 486.3 & 1.094 \\
1998 & 19.1 & 817.5 & 0.864 & 16.8 & 558.2 & 1.093 \\
2000 & 7.6 & 1058.1 & 0.705 & 7.7 & 1076.4 & 0.698 \\
2001 & 7.0 & 1326.4 & 0.675 & 7.0 & 1348.3 & 0.675 \\
\hline
\end{tabular}

Note: $1990-98$ indicators are calculated from data of 29 provinces, municipalities and autonomous regions, with Tibet excluded and Chongqing included in Sichuan for 1990-98; 2000-01 indicators are calculated from data of all 31 provinces, municipalities and autonomous regions in mainland China.

Source: 1990-98 figures from Wong, C., 2002. Issues of Equalization in China, presentation to Intergovernmental Fiscal Relations in East Asia Workshop, Bali, 10-11 January. 2000-01 figures from authors' own calculation. 
period from year 0 to year $T$; and $\beta$ is a convergence coefficient. A positive (negative) $\beta$ indicates convergence (divergence); that is, regions with higher per capita GDP level in the base year have a higher (lower) growth rate. Ma finds that the transfer payment variable is not included, $\beta$ is between -0.012 without regional dummy and -0.021 with regional dummy and is statistically significant. If the transfer variable is included, the coefficient of transfer payment $(\gamma)$, is significant and positive, and the value of $\beta$ falls to -0.018 and -0.023 , respectively, without and with regional dummy. From these results, Ma concludes that the 'transfer widens regional gaps'.

We believe, however, that the above results should be interpreted in the opposite direction. Although regional economic growth diverges, transfer payments help to mitigate this trend. In Equation 23.5, $\beta$ captures all the impacts on regional growth, whilst in Equation 23.6 it captures other impacts except transfer payments. As the value of $\beta$ in Equation 23.5 is smaller in absolute value than in Equation 23.6, the regional growth is less divergent if the transfer payments are included than if they are not. This may become clearer from the following derivation.

According to the estimates made earlier, the transfer payment received by a particular region is negatively related to its GDP level. For convenience, this relationship may be written as

$$
\operatorname{TRANSF}_{i}=\bar{T}-\alpha_{i} \ln Y_{i 0}
$$

where $\bar{T}$ is a fixed amount which is independent of regional income, $\alpha_{i}$ is a positive coefficient which is region specific. Replacing TRANSF $F_{i}$ with the above relationship, Equation 23.6 becomes

$$
\ln Y_{i T}-\ln Y_{i 0}=C+\gamma \bar{T}-\left(1-e^{-\beta T}+\gamma \alpha_{i}\right) \ln Y_{i 0}+\varepsilon_{i}
$$

It is clear from comparing Equation 23.5 with Equation 23.6' that $\beta$ in Equation 23.5 includes the effect of transfer payment $\gamma \alpha_{i}$.

The above discussion reveals that, during 1995-2000, regional gaps in per capita incomes were widening at a rate of 1.2-2.1 per cent per annum. However, if there were no transfer payments, the widening rate would have been 1.8-2.3 per cent.

\section{OUTSTANDING ISSUES}

Although the above analysis shows that transfer payments have played a positive role in improving regional disparities in recent years, it does not imply that the system is problem-free. In fact, many imperfections have been associated with this system. 
First, the structure of the transfer payments is problematic. As shown in Table 23.1 and Figure 23.2, general-purpose grants account for only 15 per cent of total transfer payments. Within the category of general-purpose grants, only the transitional transfer', which accounts for less than 7 per cent of general-purpose grants or 1 per cent of total transfer payments, is dedicated for the purpose of 'equalisation'. Most of the grants are still allocated for special purposes. For example, about half of the general purpose grants were used to increase payments to public servants and improve the social security system. This structure gives little flexibility for local governments to arrange the use of transfer payments according to their own needs. Moreover, special purpose grants often require matching funds from the recipient regional governments. This arrangement may have two negative impacts. First, it may in fact increase rather than decrease the tax burden on recipient regions as these regions have to raise the matching funds. Alternatively, the recipient governments may try to divert the earmarked grant to other purposes, thus corrupting the fiscal discipline.

The second problem of the current fiscal and transfer payment system is that it does little to deal with extra-budgetary and off-budget revenues, which include user charges for government provided goods and services, administrative fees for government services and incomes from government-owned enterprises. Local governments have good reason to collect extra-budgetary and off-budget revenues under the tax-sharing system because they are responsible for providing vital public services, such as education, health care, social security and welfare, ${ }^{4}$ but their budgetary revenues are not enough to fund the provision of these services. As a result, the magnitude of extra-budgetary revenues is equivalent to that of budgetary revenues. For example, extra-budgetary and budgetary revenues in 1999 were equivalent to 12 and 14 per cent of GDP respectively (Wong 2001, 2002b). This huge amount of extra-budgetary revenues and expenditures not only makes budgetary management more difficult, but also widens regional gaps in regional government fiscal capacity and government services. For example, in 2001, the World Bank ranked China $61^{\text {st }}$ out of 191 countries in overall quality of health, but $188^{\text {th }}$ in terms of fairness in financial contribution (World Health Report 2000, cited in World Bank 2001). One of the two fieldwork counties referred to in World Bank (2001) could not provide six years of primary schooling.

The third problem is the uneven tax burden on local economies. Figure 23.4 plots each province's average tax rate-the ratio of total taxes collected by the central 
and local governments from a province to that province's total GDP_-against its per capita GDP. The relationship displays a U-shape: the most developed and the least developed provinces have higher tax rates than the middle-income provinces. It becomes clearer if the provinces are grouped into the three regions as shown in Figure 23.5-the Western region has the highest average rate (12 per cent), followed by the Eastern region ( 10.8 per cent) and the Central region ( 9.2 per cent). This tax disparity not only further distorts the economy, but also hinders economic development in the least developed regions.

Finally, those involved in the discussion and design of a transfer payment scheme were preoccupied by equity criteria; although efficiency criteria are also important. Jiang (2003) shows that simply transferring funds from the Eastern coastal region to inland regions may reduce total welfare even though the regional gap might be narrowed. This is because the coastal region has better infrastructure, a higher technology level and a more market-oriented policy environment. Thus returns to resources are higher than those of the inland regions.

\section{STYLISED SIMULATION OF INCREASING TRANSFER PAYMENTS TO INLAND REGIONS}

The above discussion reveals that transfer payments in China have helped slow the trend of worsening regional disparity. However, the effect has been limited by the structure and scope of those programs. This section simulates different programs of increasing transfer payments to inland regions using a general equilibrium model of the Chinese economy with regional details (CERD).

\section{Description of the model}

This subsection gives a brief introduction to the model of the Chinese economy used in the analysis. ${ }^{5}$ (For more details of the model, see Jiang 2003).

As the name suggests, CERD is a multi-regional model of the Chinese economy. In this study a simple version of CERD is used, in which Chinese provinces are grouped into East, Central and West regions, as defined above. ${ }^{6}$

CERD uses the 'bottom-up' approach. Each region in CERD is treated as an open economy with its own agents and behavioural functions (Figure 23.6). Agents in each region make their decisions on the demand for, and supply of, commodities and primary factors, and regional economies are linked through commodity and factor flows. 
Figure 23.4 Provincial average tax rate versus per capita GDP, 2001

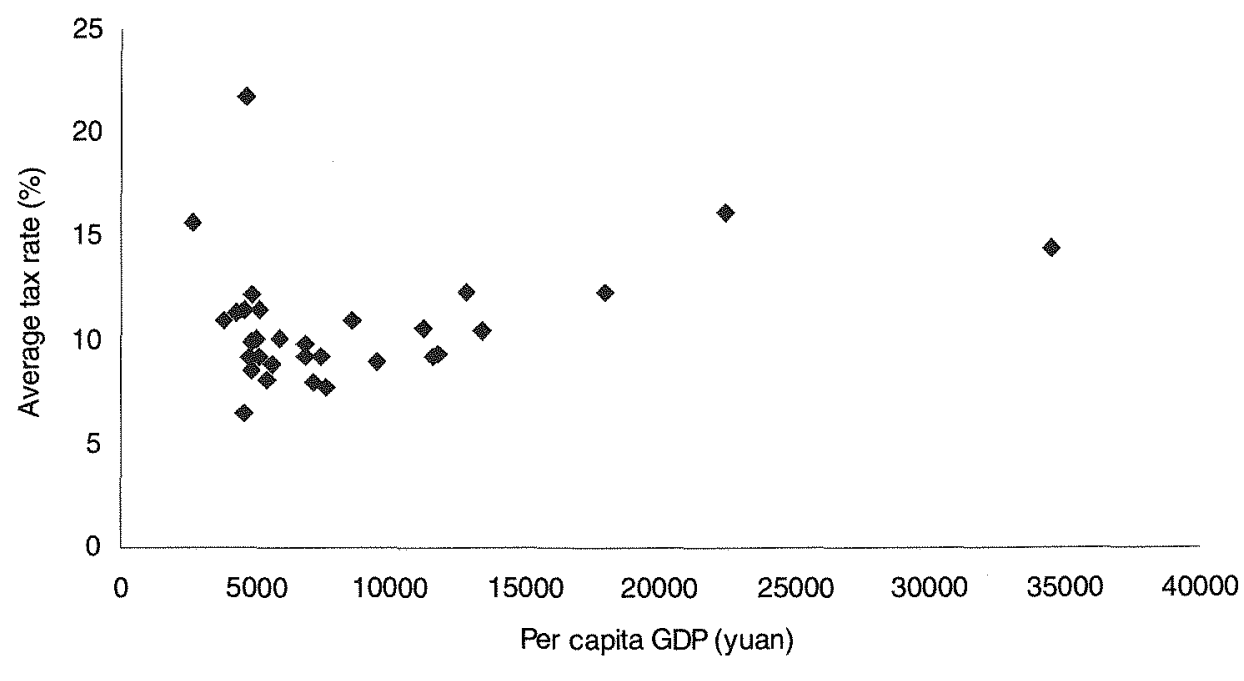

Source: Authors' construction.

Figure 23.5 Regional average tax rate, 2001

14

12

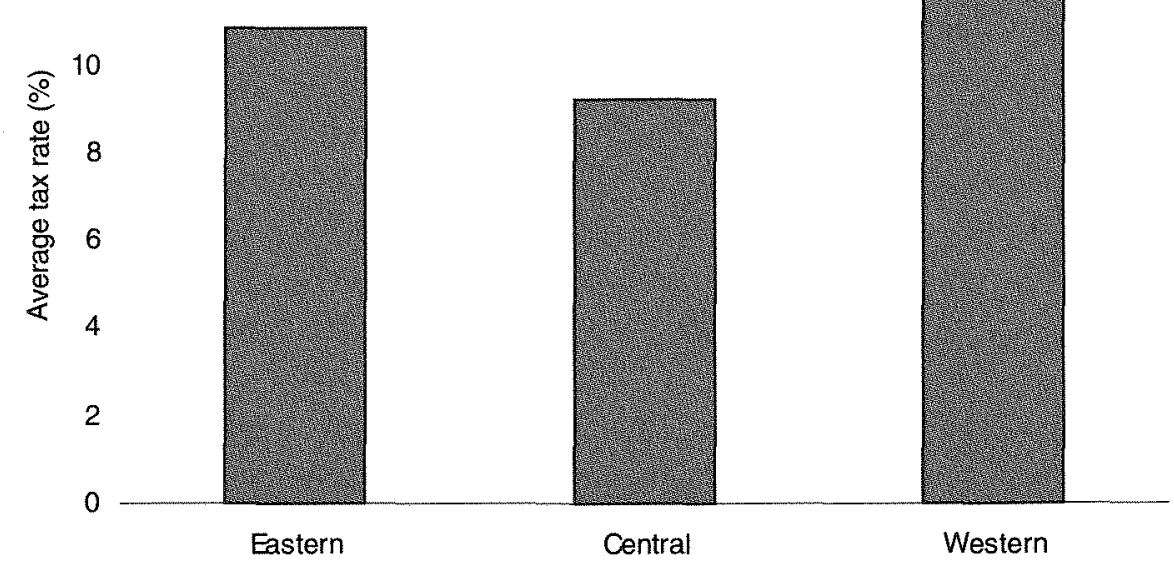

Source: Authors' construction 
It can be seen from the diagram that CERD mimics a global model of multiple regions as in the GTAP model (Hertel 1997). However, it has some peculiar features. First, regional links in CERD are more intensive than in a global model, especially for the movement of primary factors. Four types of labour are identified in CERD: urban labour, rural agricultural labour, rural non-agricultural labour and migrant labour. It is assumed that urban labour and rural migrant labour engage in non-agricultural activities only. CERD also assumes perfect mobility of capital across domestic regions and sectors.

As labour and capital can move across regional boundaries, it is important to distinguish between the usage and ownership of these factors, in order to calculate regional household income and consumption more accurately.

Another feature of CERD is that rural and urban households are distinguished in each region according to their possession of primary factors. This is appropriate for an analysis of the Chinese economy, where rural and urban areas are still separated to some degree because of various restrictions, although significant improvements have been made. For example, the household registration system, which identifies a person as a rural or urban resident, is still in effect and prevents people from freely moving across regions, especially from the countryside to cities.

Another difference between CERD and other global models lies in its treatment of regional links. Ideally, inter-regional flows of commodities and factors would be presented in the model, however, such information is not available as there are no 'customs' in each province to register 'imports' from and 'exports' to other provinces. In order to avoid arbitrary decisions in creating the database, CERD models interregional trade indirectly via a national pool of commodities and factors. Each region sells its excess supply to and buys excess demand from the national pool. For example, as shown in Figure 23.7, migrant labour in the national pool is a constant elasticity of substitution (CES) aggregation of migrant labour supplied by each region. The aggregate migrant labours are then allocated to each region to meet regional demand according to a constant elasticity of transformation (CET) process. The CES and CET processes represent regional differences in migrant labour supply and demand.

CERD also distinguishes between regional and national governments, which allows for the analysis of transfer payments. To simplify the treatment, it is assumed that tax collections (except import tariffs and export taxes), government saving and consumption are made by regional governments, while the central government serves 


\section{Figure 23.6 Structure of CERD}

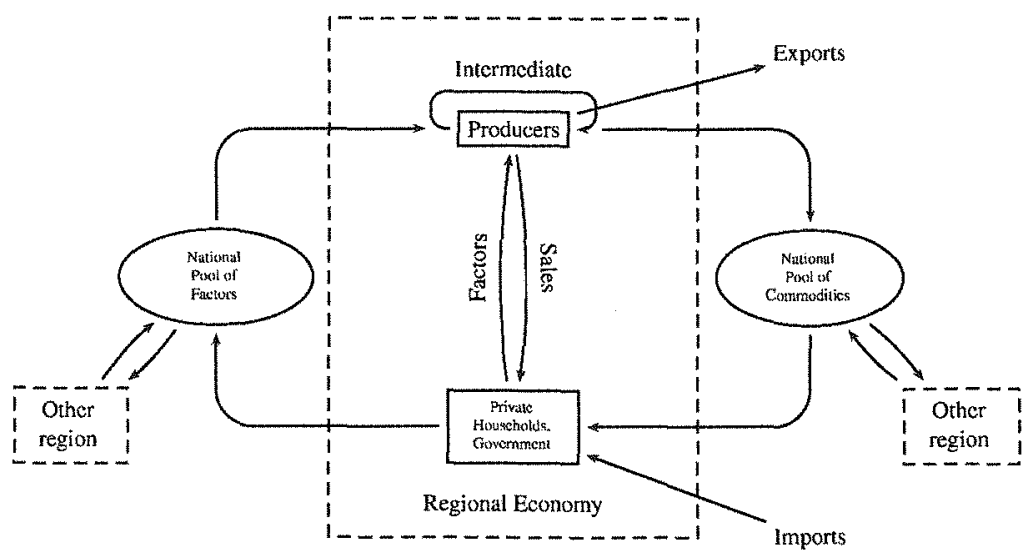

Figure 23.7 National migrant labour market

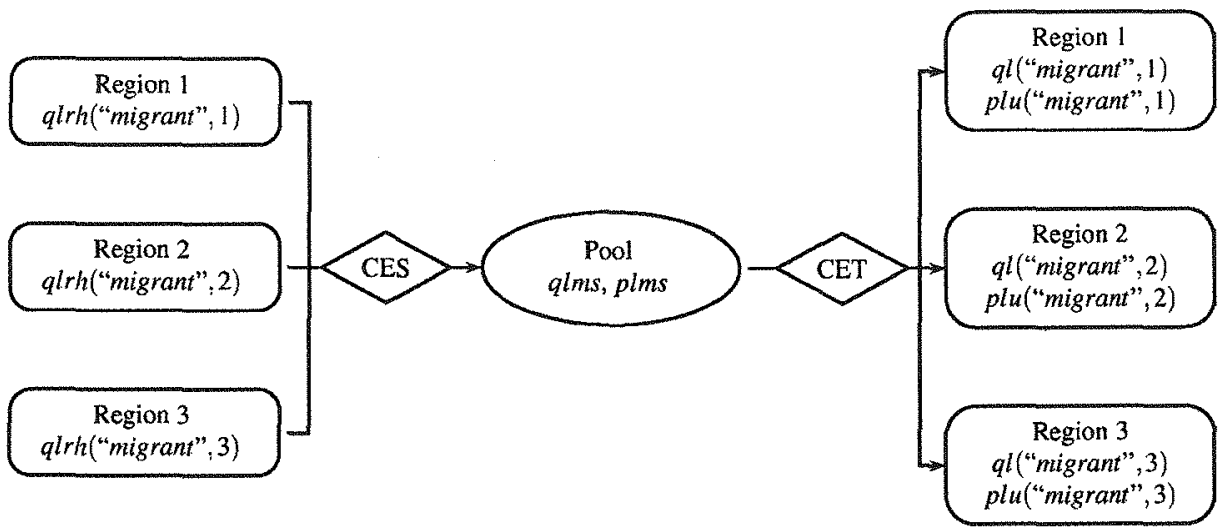


only to transfer payments to regional governments. ${ }^{7}$ Therefore, each regional government's revenue is the regional tax revenues plus transfers from the central government.

There are two closures in modelling regional governments' behaviour, namely, exogenous revenues and exogenous expenditures. In the former closure, regional tax rates and transfer payments are fixed; consequently local governments allocate the resultant revenues to government saving and consumption. On the other hand, in the latter closure, local governments' expenditures on saving and consumption are fixed at pre-defined levels, while the tax rates or the amounts of transfer payment vary to balance their budgets.

CERD gives a reasonably detailed representation of commodities with 44 sectors in each region, including 5 agricultural sectors, 25 industrial sectors, one construction sector, and 13 service sectors.

A particular feature of CERD is that its database has been compiled based on the provincial 44-sector input-output tables for 1997. The 44-sector classification follows the 40-sector classification in the 1997 national input-output table (National Accounts Department 1999) with the agricultural sector further disaggregated into five sectors. In total, there are 28 provincial tables available. ${ }^{8}$ These provincial input-output data have been aggregated into three regions. Other data and parameters are drawn from GTAP database 5, Yang and Huang (1997) and the China Statistics Yearbookseries.

\section{Stylised simulations}

Three stylised changes in transfer payments are simulated using the CERD model described above. All these simulations are centred on increasing transfer payments to the Central and Western regions by 9.2 and 12.0 billion yuan, respectively, or 10 per cent of each region's general purpose grant in 2001. However, different treatments are made in each simulation. A summary of these simulations is given in Table 23.4.

Table 23.4 Summary of simulations

\begin{tabular}{lll}
\hline Simulation 1 & Simulation 2 & Simulation 3 \\
Increase transfer payment to & Changes in transfer & Changes in transfer \\
central and western regions by & payments as set in & payments as set in \\
9.2 and 12.0 billion yuan, & Simulation 1 & Simulation 1 \\
respectively & Fixed government spending & Fixed regional tax rates \\
& Endogenous regional tax rates Improvement in input efficiency \\
& & to prevent welfare loss
\end{tabular}


The first simulation is carried out with an exogenous revenue closure. Regional tax rates are fixed and regional governments' revenues changes along with the changes in transfer payments. ${ }^{9}$

The second simulation is carried out with an exogenous expenditure closure. Regional governments' expenditures are fixed, and the increase in transfers to central and western regions is used to bring down the tax rates in these regions.

The third simulation takes the efficiency issue into consideration. As mentioned above, improving regional disparity through pure transfer payments may actually reduce total welfare. However, it is also possible for transfer payments to increase total welfare through improving the productivity in less developed regions. However,

Table 23.5 Simulation results of increasing transfer payments to inland regions

\begin{tabular}{|c|c|c|c|}
\hline & Simulation 1 & Simulation 2 & Simulation 3 \\
\hline \multicolumn{4}{|c|}{ Equivalent variation (billion yuan) } \\
\hline Eastern & -25.7 & -21.2 & -25.8 \\
\hline Central & 9.9 & 11.2 & 11.8 \\
\hline Western & 12.7 & 15.2 & 13.9 \\
\hline Total & -3.0 & 5.2 & -0.0 \\
\hline \multicolumn{4}{|c|}{ Regional utility (per cent) } \\
\hline Eastern & -0.4 & -0.4 & -0.4 \\
\hline Central & 0.4 & 0.5 & 0.5 \\
\hline Western & 0.8 & 1.0 & 0.9 \\
\hline \multicolumn{4}{|c|}{ Real consumption (per cent) } \\
\hline Eastern & -0.9 & -0.3 & -0.9 \\
\hline Central & 0.3 & 0.4 & 0.4 \\
\hline Western & 0.9 & 1.1 & 0.9 \\
\hline \multicolumn{4}{|c|}{ Regional CPI (per cent) } \\
\hline Eastern & 0.0 & -0.0 & 0.0 \\
\hline Central & 0.1 & 0.1 & 0.1 \\
\hline Western & 0.3 & 0.4 & 0.3 \\
\hline \multicolumn{4}{|c|}{ Real GDP (per cent) } \\
\hline Eastern & 0.0 & -0.4 & 0.0 \\
\hline Central & -0.0 & 0.4 & 0.1 \\
\hline \multirow[t]{2}{*}{ Western } & 0.0 & 1.0 & 0.1 \\
\hline & & (percentage points) efficiency & $\begin{array}{l}\text { Output } \\
\text { efficiency }\end{array}$ \\
\hline Eastern & & 0.1 & 0.0 \\
\hline Central & & -0.1 & 0.0 \\
\hline Western & & -0.4 & 0.0 \\
\hline
\end{tabular}


we do not have sufficient concrete information to establish the relationship between transfer payments and productivity improvement to be included in the CERD. Rather, we proceed in the opposite direction, asking how much productivity improvement is required to offset the inefficiency brought about by transfer payments. This simulation is also carried out with an exogenous revenue closure. The simulation results are summarised in Table 23.5. Several points may be made in relation to these results.

First, increased transfer payments to inland regions can improve regional inequality. For example, in Simulation 1, the Western region benefits the most, with household and government utility increases by 0.89 per cent, followed by the Central region, with utility up by 0.48 per cent, while the Eastern region suffers, with utility down by 0.4 per cent because increased transfer payments to inland regions are financed with decreased transfer payments to the Eastern region.

Second, a pure increase in transfer payments (Simulation 1) is welfare decreasing. Although the equivalent variations (EV) in the Central and Western regions increase by 9.9 and 12.7 billion yuan, respectively, the Eastern region's equivalent variation decreases by 25.7 billion yuan, causing a net loss of 3.0 billion yuan. This is because the inland regions have lower returns to resources. Although the impacts of Simulation 1 are mainly on the demand side and the real GDP virtually does not change, the lower returns in inland regions are represented by lower utility of household and government savings in these regions.

Third, reducing tax rates in inland regions through higher transfer payments may increase total welfare. This is because the reduction in tax rates would provide additional stimulus to the regional economy. For example, tax rates decrease by 0.17 and 0.40 percentage points in the Central and Western regions, respectively, leading to increases in real GDP by 0.42 and 1.03 per cent, respectively.

Finally, a 10 per cent increase in general purpose grants to inland regions requires a 0.04 per cent generic improvement in output efficiency in these regions in order to keep total welfare unchanged.

\section{CONCLUSION}

China's governmental transfer payment scheme has been evolving along with the fiscal regime. The implementation of the Transfer Payment Arrangement during the transitional period in 1996 marked the establishment of a formal and comprehensive program of governmental transfer payments. It has played a positive role in easing regional inequality. However, the scheme has some imperfections. Most importantly, the amount of transfer payments aimed at 'equalisation' is limited. 
Using a general equilibrium model of the Chinese economy with regional dimensions, several approaches to increasing transfer payments to inland regions have been simulated. It was found that a pure transfer payment increment would decrease total welfare, as the decline in the Eastern region's welfare more than offsets the gains in the inland regions. In order to keep the total welfare unchanged, a 0.04 per cent generic improvement in regional output efficiency is required for a 10 per cent increase in general purpose grants to the inland regions.

It was also shown that, if an increase in transfer payment were used to reduce tax rates in the inland regions, total welfare nationwide could be improved. This may have some implications for the so-called 'tax for fee' reform which aimed at reducing the tax (fee) burden by replacing various administrative fee schemes implemented by regional governments with a uniform tax system. As the 'tax for fee' reform usually reduces governments' revenue in less developed regions, the central government should provide enough transfer payments for these governments to fulfil their duties. Otherwise, local governments may simply reduce vital public services.

\section{NOTES}

1 Thirty-one provinces, municipalities and autonomous regions in mainland China are normally classified into three regions--Eastern coastal, Central and Western regions-according to their geographical location and economic development situation. The Eastern coastal region is the most developed region in China and contains 12 provinces and municipalities-Beijing, Tianjin, Hebei, Liaoning, Shanghai, Jiansu, Zhejiang, Fujian, Shandong, Guangdong, Guangxi and Hainan. The Central region includes nine provinces and autonomous regions with a middle degree of economic development: Shanxi, Inner Mongolia, Jilin, Heilongjiang, Anhui, Jiangxi, Henan, Hubei and Hunan. The Western region is the least developed region and contains the remaining six provincesYunnan, Guizhou, Sichuan, Shaanxi, Qinghai and Ganshu; three autonomous regions-Tibet, Ningxia and Xingjiang; and one municipality-Chongqing.

2 This system was intended to reinforce the fiscal power of the central government, which had eroded under the fiscal contract system.

3 Wong (2002) does not give an exact definition of per capita expenditure and revenue. It is conjectured that she includes both budgetary and extra-budgetary expenditure and revenue, which may explain the inconsistency between her numbers and those in Jin el al. (1999).

4 According to the World Bank (2001), governments at county and township level spend 70 per cent of budgetary expenditure on education, and 55-60 per cent on health. Cities at the prefecture and county levels use all expenditures on unemployment benefits and social security. 
5 For more details of the model, see Jiang (2003).

6 The detailed version of the CERD model identifies 28 regions, each of which corresponds to one province, autonomous region or municipality directly under the central government in mainland China, with exceptions where Hainan, Ningxia and Tibet are included in Guangdong, Gansu and Qinghai respectively.

7 If the central government is allowed to consume, it should make decisions about where the commodities it consumes are bought and sold as well as how much of them it consumes. This would unnecessarily increase the burden of computation as it can be embodied in the decisionmaking process of individual regional governments.

8 Three provinces or autonomous regions, Hainan, Ningxia and Tibet, do not have input-output tables. These regions are small in economic scale and their input-output data were constructed on the basis of information about neighbouring regions with similar natural and economic characteristics. Specifically, Hainan is included in Guangdong, Ningxia in Gansu, and Tibet in Qinghai.

9 More accurately, government revenue is endogenous even in this 'exogenous revenue' closure case because it is also affected by the tax base, which is endogenous. The effect, however, would be of second order.

\section{REFERENCES}

Du, F., 2001. Theory and Practices of Intergovernmental Fiscal Transfer Payments, Publishing House of Economic Science, Beijing.

Fan, M. and Zheng, Y., 2000. The Impact of China's Trade liberalisation for WTO Accession: a computable general equilibrium analysis, Paper presented at the Third Annual Conference on Global Economic Analysis, Monash University, Australia, 27-30 June. Available online at http://www.monash.edu.au/policy/conf/ 42fan.pdf.

He, C., 2001. The Main Situations of Inter-governmental Fiscal Transfer Payment in China, Paper presented in the International Symposium on Fiscal Transfer Payments, Kunming, Yunnan, 3-5 September.

Hertel, T.W.(ed.), 1997. Global Trade Analysis: modeling and application. Cambridge University Press, Cambridge and New York.

Jiang, T., 2002. 'WTO accession and regional incomes', in R. Garnaut and L. Song (eds), China 2002: WTO entry and world recession, Asia Pacific Press, Canberra:45-62.

Jiang, T., 2003. 'The impact of China's WTO accession on its regional economies', Australian Agribusiness Review, forthcoming. 
Jin, H., Quian, Y., and Weingast, B.R., 1999. Regional decentralisation and fiscal incentives: federalism, Chinese style, Stanford University, Stanford, unpublished. Ma, J., 1998. Transfer Payments, Publishing House of Economic Science, Beijing. $\mathrm{Ma}, \mathrm{S} ., 2003$. Transfer and narrowing regional gap, Institute of Finance and Trade, Chinese Academy of Social Sciences, Beijing, unpublished.

Ministry of Finance Budget Department, 2003. Intergovernmental Fiscal Relations in China, China Finance and Economics Press, Beijing.

National Accounts Department, State Statistical Bureau, 1999. Input-Output Table of China 1997, China Statistical Press Beijing.

State Statistical Bureau, various issues. China Statistical Yearbook, China Statistical Press, Beijing.

Sun, H., 2000. 'Economic growth and regional disparity in China', Regional Development Studies, 6:43-66.

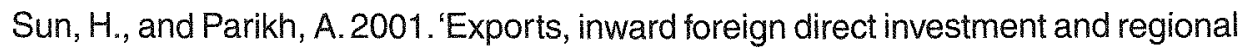
economic growth in China', Regional Studies, 35(3):187-96.

Wong, C., 2001. Fiscal Decentralization in China: the problematic outcomes of unplanned changes in transition towards a market economy, Paper presented to the Asian Development Forum, Bangkok, 11-14 June.

Wong, C., 2002a. Issues of Equalization in China, Paper presented to Intergovernmental Fiscal Relations in East Asia Workshop, Bali, 10-11 January. Wong, C., 2002b. Characteristics of China's Intergovernmental System, Paper presented to Intergovernmental Fiscal Relations in East Asia Workshop, Bali, 10-11 January.

World Bank, 2001. China: provincial expenditure review, World Bank, Washington, DC.

Wu, Yanrui, 1999. Income Disparity and Convergence in China's Regional Economies, Discussion Paper 99-15, Department of Economics, University of Western Australia. Available online at www. econs.ecel.uwa.edu.au/economics/dpapers / DP1999/9.15.pdf [accessed 2 January 2002].

Yang, Y., and Huang, Y., 1997. The Impact of Trade Liberalisation on Income Distribution in China, China Economy Working Paper 97/1, Research School of Pacific and Asian Studies, The Australian National University, Canberra.

Zhang, Z., 2002. Intergovernmental Fiscal Relations in P.R. China, Paper presented to Intergovernmental Fiscal Relations in East Asia Workshop, Bali, 10-11 January. 